\title{
Monitoring of consolidation behaviour of marine clay treated with vacuum and surcharge at the Port of Brisbane
}

\author{
B Indraratna University of Wollongong, Australia \\ AS Balasubramaniam Griffith University, Australia \\ H Poulos Coffey Geotechnics, Australia \\ C Rujikiatkamjorn University of Wollongong, Australia \\ J Ameratunga Coffey Geotechnics, Australia \\ D Perera University of Wollongong, Australia
}

\begin{abstract}
Over the past decade, the application of vacuum preloading for stabilising reclaimed soil and other low-lying estuarine soils has become popular in Australia. Its cost effectiveness is a governing factor in view of the reduced consolidation time to achieve a relatively high degree of consolidation. Due to demand in trade activities at the Port of Brisbane, new port facilities have been constructed on reclaimed land. A vacuum and fill surcharge, in conjunction with prefabricated vertical drains, was selected to accelerate consolidation time of the thick layers of subsoil. A performance comparison of a combined vacuum and fill surcharge loading system with a standard surcharge fill highlights the clear advantages of vacuum consolidation. Field data demonstrate how the embankment performed during construction. This paper also assesses the relative performance of the two contrasting preloading systems (i.e. vacuum and non-vacuum system).
\end{abstract}

\section{Introduction}

Coastal regions contain soft clays, which possess unfavourable geotechnical properties such as, low undrained shear strength and high compressibility. Excessive settlement and lateral movement can pose an issue on the stability of structure built on such soft ground (Holtz et al. 1991; Indraratna \& Redana 2000). A system of vertical drains with a vacuum and fill preloading is a popular technique to accelerate soil consolidation. The performance of the system can now be predicted with an acceptable accuracy through rigorous analytical and numerical analysis. Mohamedelhassan and Shang (2002) introduced an analytical solution for vacuum application under 1D consolidation. Indraratna et al. (2005) proposed the unit cell radial consolidation theory for vacuum application considering the vacuum distribution along the drain length. Chu et al. (2000) and Chai et al. (2005) demonstrated the application of the vacuum preloading combined with prefabricated vertical drains (PVDs) can distribute the suction to a greater depth of the subsoil. Also, consolidation time can be minimised as multi-staged embankment construction can be avoided (Indraratna et al. 2005; Sathananthan et al. 2008). The required fill height may be lowered by several metres, via vacuum application (Rujikiatkamjorn et al. 2008). Once the compressibility of soil is decreased with increased shear strength due to consolidation, the long term settlement can be considerably less (Shang et al. 1998). To date, there is no comprehensively reported case history where both the conventional surcharge preloading and vacuum technique are applied in the same area with different drain types and spacing.

In this paper, the comparison of performance between the vacuum and non-vacuum application was made based on the measured vertical and lateral deformations, excess pore pressures and long term settlement. The factors including drain spacing and drain type are elaborated based on the observed degree of consolidation. 


\section{Site descriptions}

The Port of Brisbane is the third largest port in Australia located at the gateway of the Brisbane River (Indraratna et al. 2011). With rapid development in trading activities, a new area (235 ha) close to the original port facilities was reclaimed to increase the available land, and the additional berths (Figure 1). In this area, the soil profile contained a compressible clay layer ( $30 \mathrm{~m}$ in thickness) with an undrained shear strength no more than $15 \mathrm{kPa}$ near the surface. On top of this layer, the shear strength of the dredged mud used for reclamation has lower shear strength depending on the drying duration. Without any preloading, it is estimated that the consolidation can be more than 50 years with vertical deformation about $2.5-4.0 \mathrm{~m}$ for the required service loading. Due to the low shear strength of dredged mud, vacuum application with PVDs was recommended to accelerate the consolidation process and to curtail lateral deformation for the area located adjacent to the Moreton Bay Marine Park (Austress Menard, personal communication, 2008).

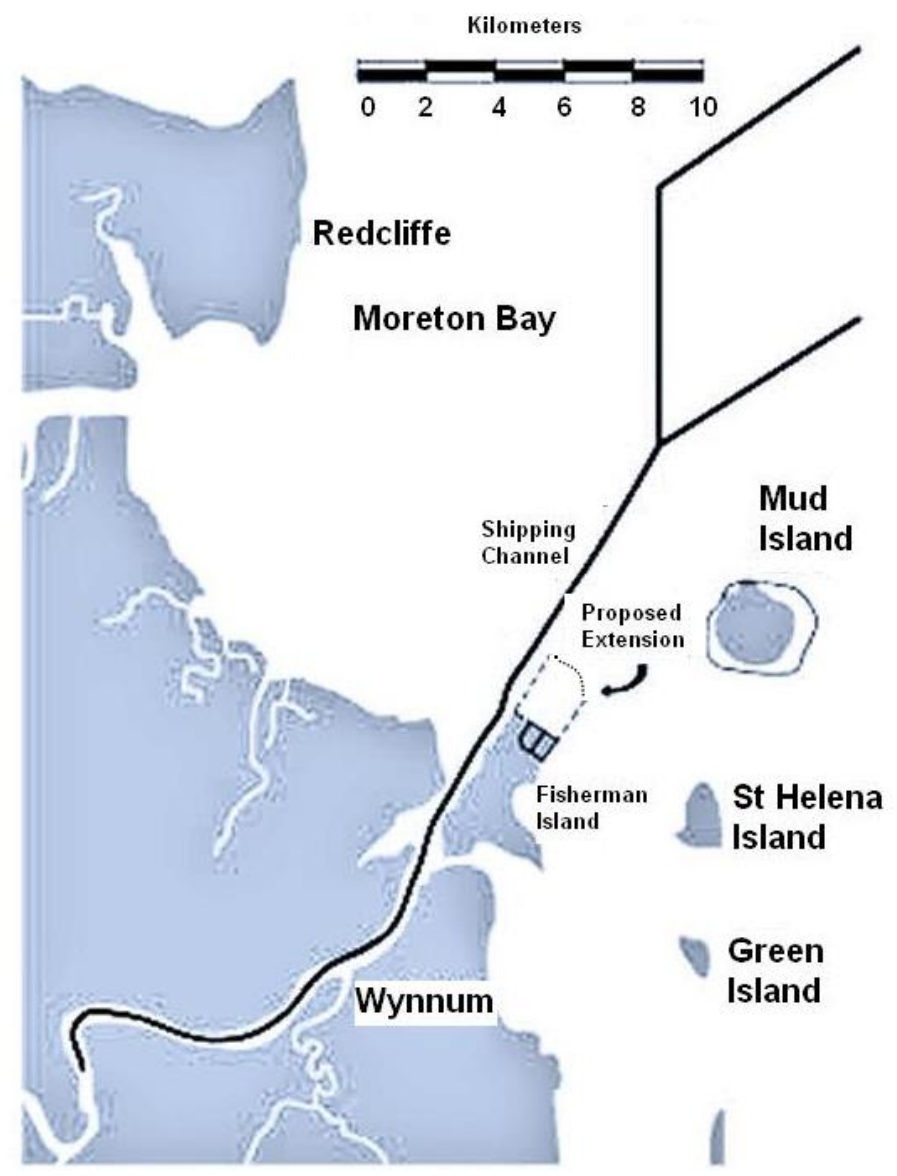

\section{Figure 1 Location of the proposed extension area at the Port of Brisbane (adopted from Port of Brisbane Corporation 2009)}

The reclaimed land will be used as additional berths and associated infrastructure to accommodate the future growth of the Port (Port of Brisbane Corporation 2009). A trial area is shown in Figure 2 to perform the performance evaluation between the vacuum and fill preloading. A total of three contractors were selected to be involved in this activity. The main objective was to compare performance based on their design and construction work.

Contractor $A$ was involved in eight trial areas in Area S3A with subdivision areas designated as WD1, WD2, WD3, WD4, WD5a, WD5b, VC 1 and VC 2. Areas WD1 to WD5a and WD5b had fill loading only, while VC1 and VC2 had fill surcharge and vacuum consolidation via membrane system.

Contractor $B$ conducted their trial in area T11 with seven sub-areas. Five of them had fill surcharge and different drain types. The rest had fill surcharge and vacuum with membraneless system. 
Contractor $C$ occupied a trial area in T11, which was divided into Areas 4,5 and 6 . Areas 4 and 5 had a fill surcharge period of 12 months, whereas Area 6 had a fill surcharge period of 6 months. PVDs with $1.4 \mathrm{~m}$ spacing were installed in Areas 4 and 5 while vertical drains in Area 6 were installed at a spacing of $1 \mathrm{~m}$.

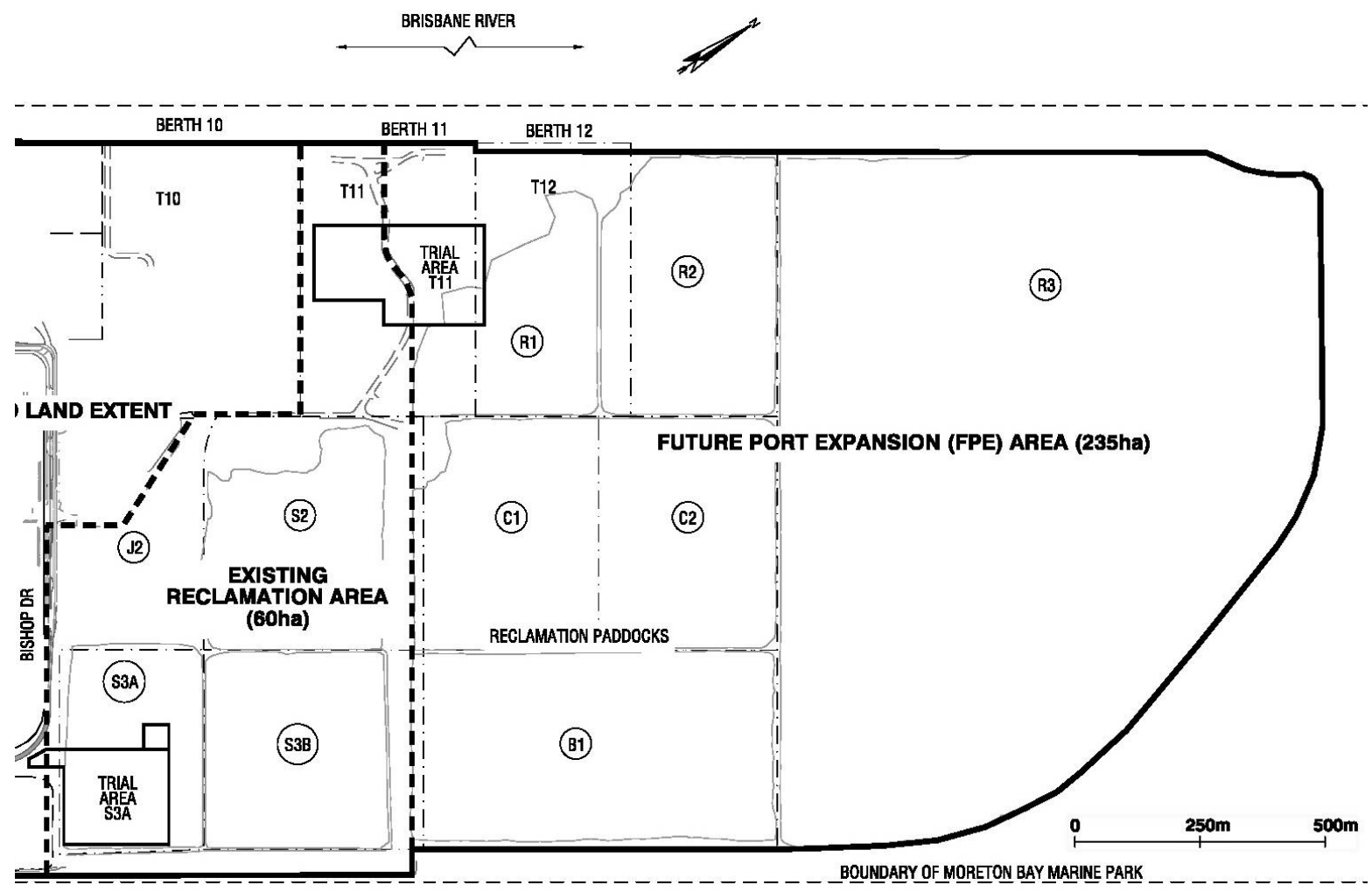

Figure 2 Trial sites

The upper Holocene sand below the dredged mud was about $2 \mathrm{~m}$ thick, and overlaid the Holocene clay layer having a thickness varying from 6 to $25 \mathrm{~m}$. The Holocene clay layer had a low shear strength and is generally referred to as PoB clay (Ameratunga et al. 2010). The Holocene layer overlies a stiff Pleistocene deposit. Site investigation techniques using cone penetration/piezocone tests, dissipation tests, boreholes, field vane shear tests and oedometer tests were performed to establish the consolidation and stability design parameters. The soil profile and the corresponding soil properties are shown in Figure 3, where groundwater level is at $+3.5 \mathrm{~m}$ RL. The water contents of the soil layers were at or beyond their liquid limits. The field vane tests indicate that the undrained shear strength of the dredged mud and the Holocene clays varied from 5 to $60 \mathrm{kPa}$. The compression index $\left(C_{c}\right)$ varied from $0.1-1.0$. The coefficient of consolidation in vertical direction $\left(c_{v}\right)$ was approximately the same as that in horizontal direction $\left(c_{h}\right)$ for the totally remoulded dredged mud layer, while $c_{v} / c_{h}$ is about 2 for the Holocene clay layer. As the Holocene clay layer is quite thick, two preloading approaches were used to minimise the long term settlement, including conventional surcharge preloading system and the vacuum consolidation system both applied to PVDs. Rigorous design specifications were considered for the design and construction of fill embankments and vacuum application over the soft Holocene deposits: (a) service load of 15-25 kPa; and (b) maximum residual settlement of not more than $250 \mathrm{~mm}$ over 20 years after the application of service load. 


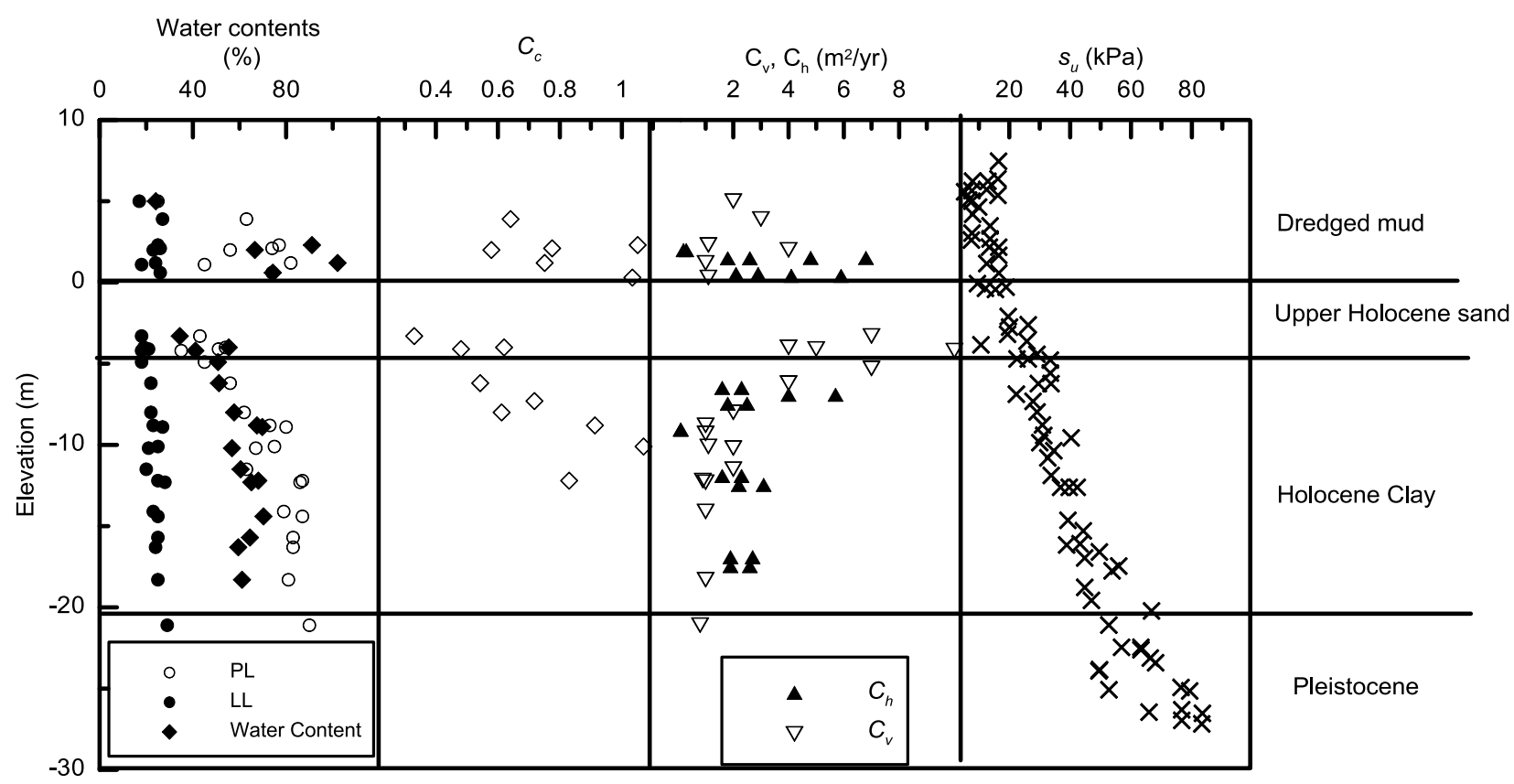

Figure 3 Soil properties and profile at S3A, Port of Brisbane (Indraratna et al. 2011)

\section{Selection of the field instruments and their reliability}

Field instruments comprise 32 settlement gauges, 76 vibrating wire piezometers and 10 inclinometers. The need for monitoring large soil deformation was the major factor in selecting the type of instrument. The reliability and accuracy of the installed instruments were determined by the equipment manufacturers after in-situ testing and calibration, and a summary is provided in Table 1. Nevertheless, during the monitoring period, a total of four piezometers and three inclinometers were found to be partly damaged or malfunctioned due to excessive lateral soil movement that caused the distortion of the casings.

Table 1 Reliability and accuracy of the installed instruments at POB

\begin{tabular}{|c|c|c|}
\hline Instrument & Accuracy & Reliability indication \\
\hline $\begin{array}{l}\text { Heavy-duty vibrating wire } \\
\text { piezometer }\end{array}$ & $\pm 0.1 \%$ full scale & $\begin{array}{l}\text { Over range capacity: } 200 \% \\
\text { full scale }\end{array}$ \\
\hline Inclinometer & $\begin{array}{c}\text { Sensor: } \pm 0.02 \% \text { full scale } \\
\text { Overall accuracy for the system (over } \\
25 \mathrm{~m} \text { length): } \pm 2 \mathrm{~mm} \text { (for } \pm 30 \text { 을 } \\
\text { inclination) to } \pm 4 \mathrm{~mm} \text { (for } \pm 90 \text { 을 } \\
\text { inclination) }\end{array}$ & $\begin{array}{c}\text { Repeatability: } \pm 0.008 \% \text { full } \\
\text { scale }\end{array}$ \\
\hline Settlement plate & $\begin{array}{c}\text { Depends on the accuracy of the } \\
\text { surveying method }\end{array}$ & $\begin{array}{l}\text { Very reliable, due to the } \\
\text { simple system (mechanical) } \\
\text { and easy access to the rod }\end{array}$ \\
\hline
\end{tabular}

\section{$4 \quad$ Performance comparison of field trials}

\subsection{Excess pore pressure}

The dimensionless $\beta$-factor is proposed to consider the drain and site loading conditions for a given depth of soil, regardless of the soil properties. It is considered to be a useful parameter that can differentiate the relative effectiveness between different methods of treatment apart from the conventional degree of consolidation, and capture the effects of: (i) increasing the drain length $\left(I_{d}\right)$; (ii) decreasing the drain spacing 
$\left(S_{d}\right)$ and its pattern ( $\alpha=1.05$ for triangular and 1.13 for square spacing); and (iii) increasing the surcharge load height $(H)$ to consolidate the given clay thickness $\left(h_{c}\right)$, represented by the ratio $\left(H / h_{c}\right)$.

In this respect, this dimensionless parameter $\beta$ can be defined as:

$$
\beta=\left(l_{d} / \alpha s_{d}\right) \times\left(H / h_{c}\right)
$$

Based on the magnitude of $\beta$ determined at each settlement plate location for S3A and T11, the drain and site conditions at the 3 trial paddocks can be differentiated as:

1. Low $\beta$ impact: 2-6 (for S3A area under Contractor $A$ ).

2. Moderate $\beta$ impact: 8-12 (for T11 area under Contractor $\mathrm{B}$ ).

3. High $\beta$ impact: $12-18$ (for T11 area under Contractor $\mathrm{C}$ ).

Figure 4 presents the decrease in pore water pressure with time, and it can be seen that VC2 in S3A shows the largest reduction closely followed by VWP3 in T11. However, since fill heights and clay thickness in S3A and T11 paddocks were not the same, these plots cannot be directly compared and most of them are clustered together during the first three months. Figure 5(a) shows the change of excess pore water pressure for the same locations, and VC2, VC1 and WD1 indicate the highest rate of excess pore pressure change at the beginning, while VC1 maintained a steady state over a long period of time. The membraneless systems do provide a higher rate of excess pore pressure dissipation in comparison with VC1 and VC2 areas. When these plots are normalised by the $\beta$-factor (Figure 5(b)), VC1 and VC2 clearly provide the best treatment based on excess pore pressure dissipation.

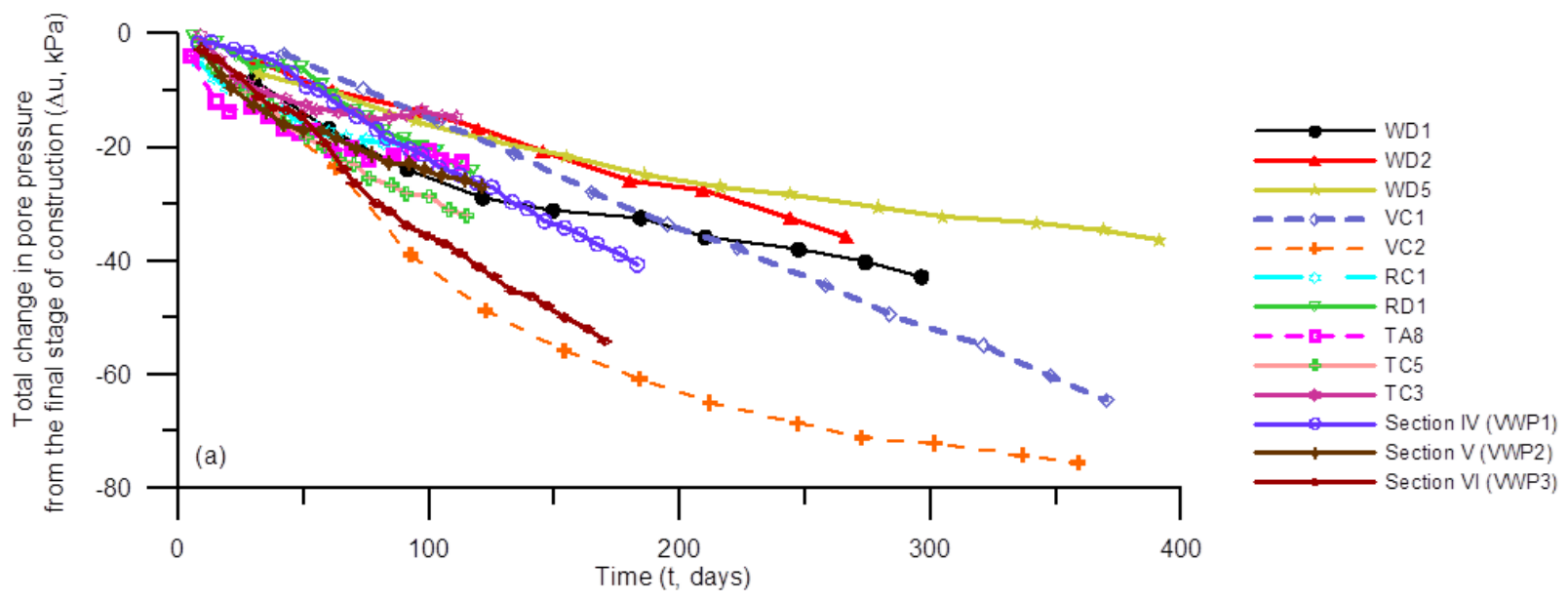

Figure 4 Rate of excess pore water pressure reduction in S3A and T11 areas 

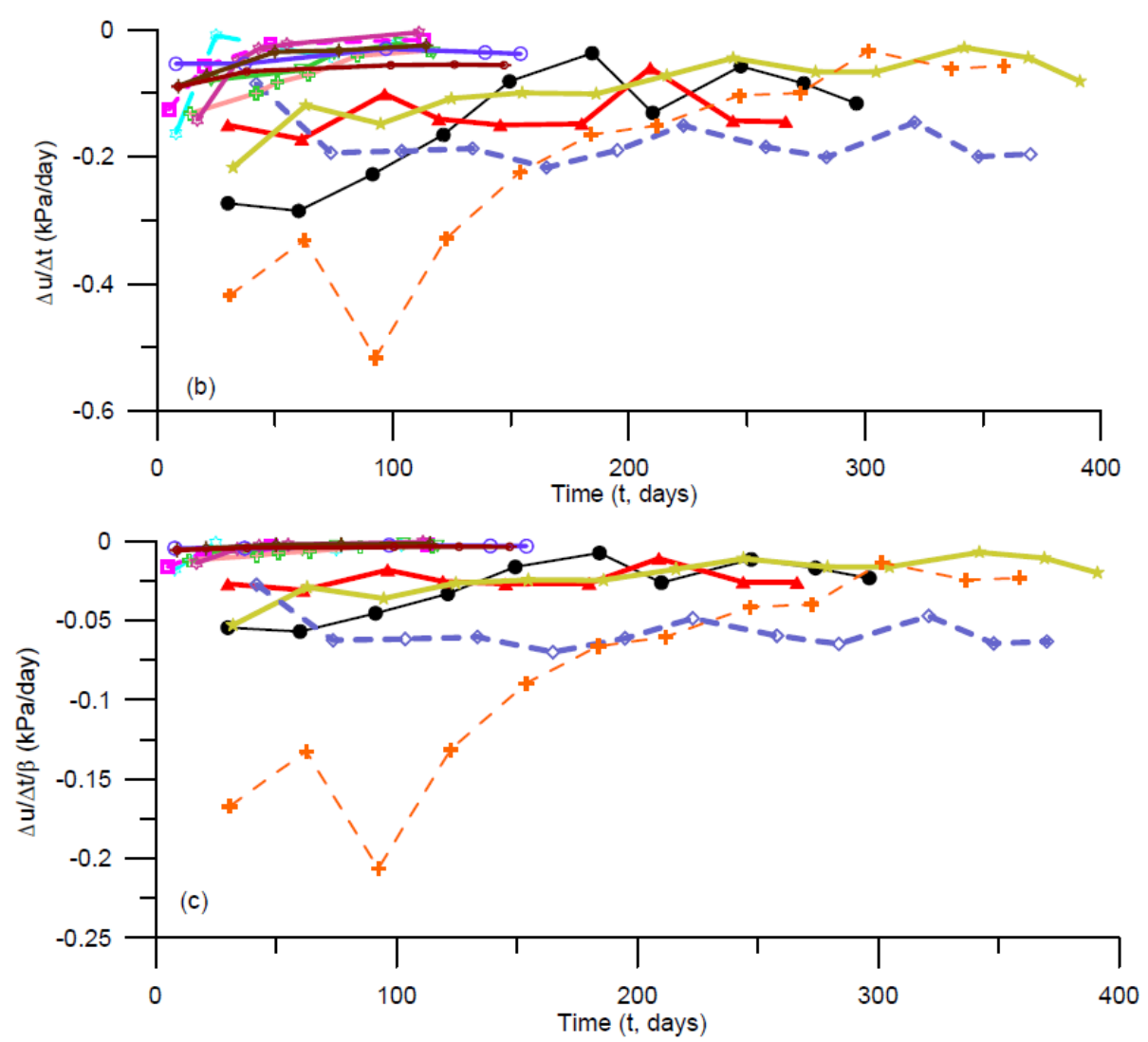

Figure 5 Comparison of excess pore pressure dissipation between S3A and T11 (a) rate of dissipation of excess pore pressure, (b) excess pore pressure dissipation rate normalised by $\beta$

\subsection{Settlements}

The numerically determined degree of consolidation (DOC) with time plots for an array of locations, and they all show a very similar behaviour, irrespective of the treatment site (S3A and T11) and the type of improvement (vacuum versus surcharge only In order to separate the 'clustering' especially towards one year, the DOC is divided by the dimensionless parameter $\beta$-factor. Figure 6 shows the variation of DOC divided by $\beta$-factor $(\mathrm{U} / \beta)$ plotted against time. This results in a separation between vacuum and nonvacuum areas, and also separates the vacuum consolidation effects of Contractors $A$ and $B$. When considering all 3 sets of plots (Figure 6), the relative consolidation performance seems more superior in the case of Contractor A treatment areas when using vacuum consolidation, in comparison with all other locations in S3A and T11.

\subsection{Lateral deformation}

It is well-known that the PVDs can reduce the lateral yield in soil and that the application of vacuum pressure further controls the lateral movement (Indraratna et al. 2005). The application of vacuum pressure to curtail lateral displacements was very important in sensitive areas such as in the vicinity of marine parks, especially at $\mathrm{POB}$ site. Only very limited field data were available from a few inclinometers. Nevertheless, in order to compare the lateral movements of selected vacuum and non-vacuum areas that have very different soil profile and surcharge load conditions, the lateral displacement can be divided by the applied effective stress at the same depth (Figure 7). These four plots clearly indicate that while vacuum consolidation can control the lateral movement, the vacuum system with $70 \mathrm{kPa}$ suction further shows the most significant reduction in the normalised lateral displacement, i.e. compare VC1-MS28 with WD3-MS27. In the Membraneless vacuum system with $50 \mathrm{kPa}$ suction, while a reduction in the lateral movement was definitely achieved (i.e. compare MS24 with MS34), the amount of this reduction is not as 
significant as that of Membrane system. The shape of the lateral displacement curves suggest that in all VC areas the suction head propagates significantly with depth such that both the lower hemi-continuous (LHC) and upper hemi-continuous (UHC) layers are favourably influenced.

TIME (days)

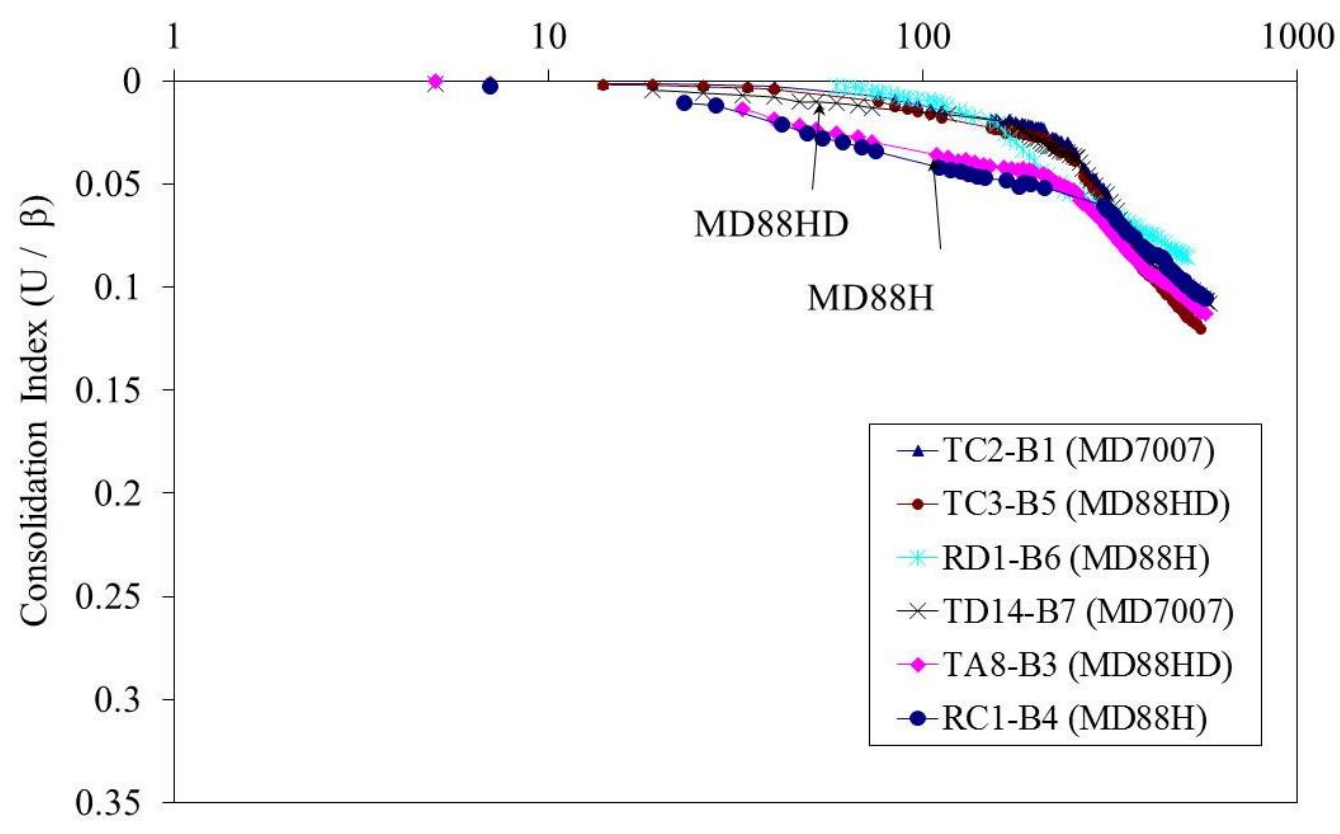

(a)

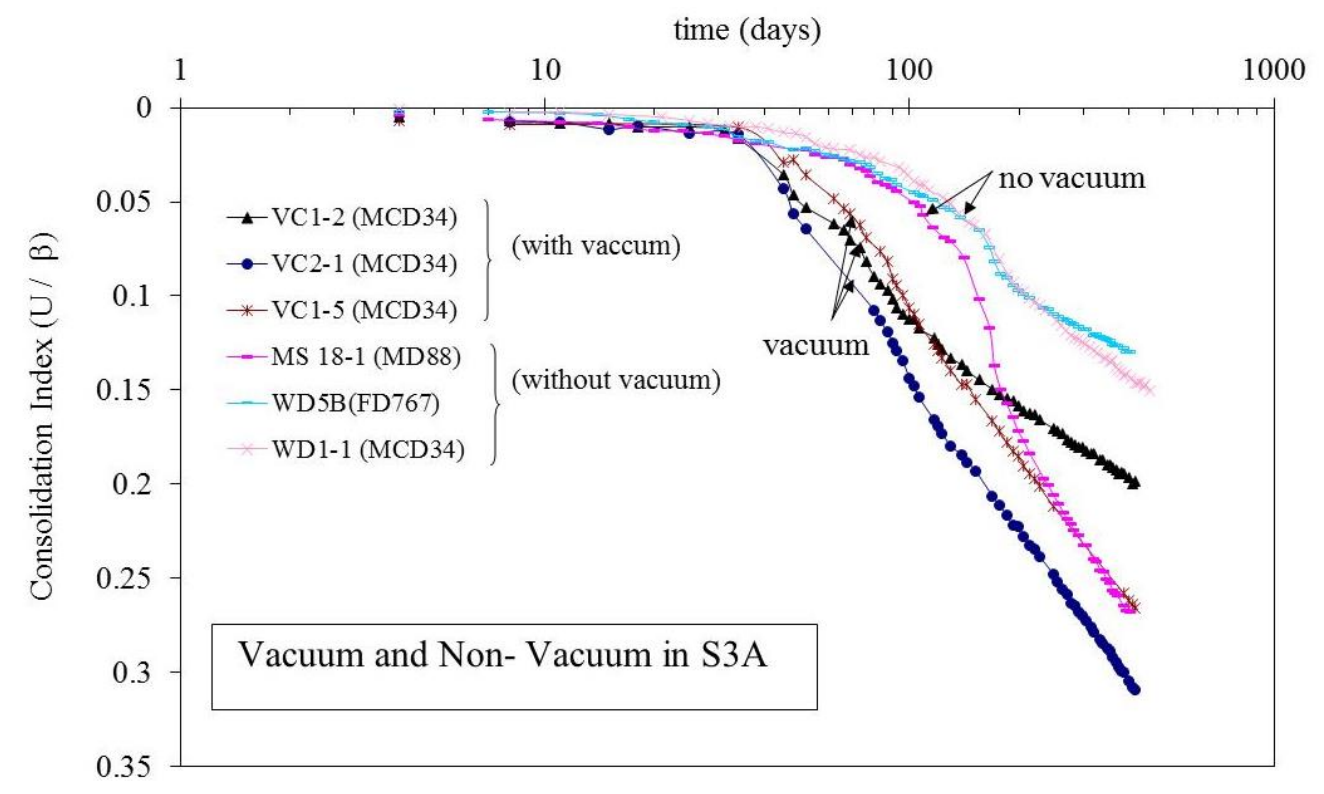

(b)

\section{Figure 6 Computed $D O C / \beta$ with time for (a) non-vacuum in S3A and T11 and (b) vacuum areas in S3A and T11}

\subsection{Predicted long term deformation (residual settlement, RS)}

In Figure 8, the values of RS for both S3A and T11 paddocks are calculated plotted with the $\beta$-factor based on methods provided by Terzaghi et al. (1996) and Yin and Graham (1994), and the observations suggest that the critical RS occurs in the range $4<\beta<16$. In this critical zone, that includes locations from all three contractors from both S3A and T11 paddocks, the RS are close to the permissible limits. At low values of 
$\beta<4$, the residual settlements are much smaller mainly because of vacuum consolidation. At very high values of $\beta>16$ (T11), the RS tend to decrease mainly because of the high fill surcharge levels compared to the clay thickness (i.e. relatively high $H / h_{c}$ ratio).

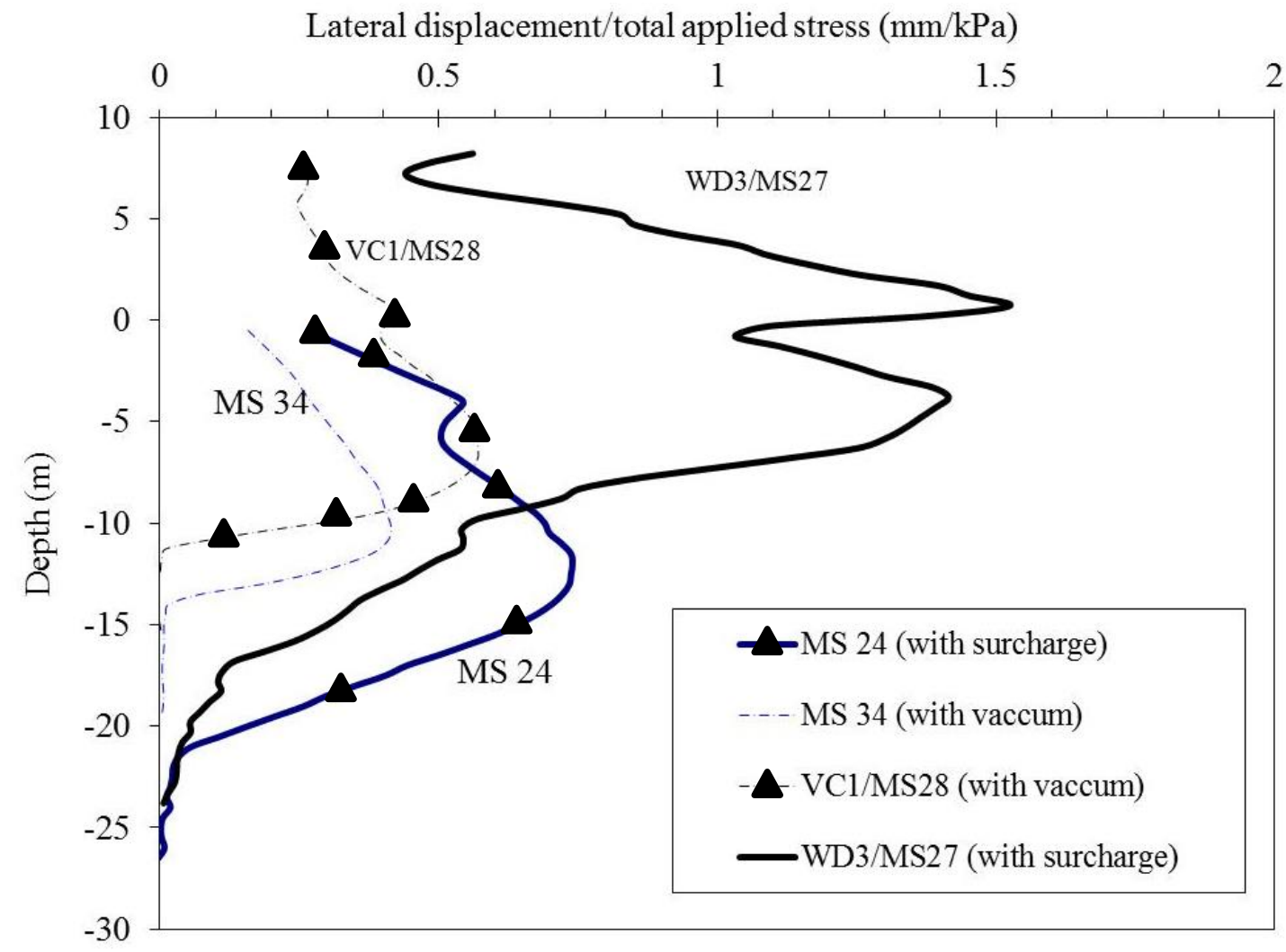

\section{Figure 7 Role of vacuum consolidation on lateral displacement}

\section{Conclusion}

A system of vertical drains with vacuum preloading is an effective method for speeding up soil consolidation. The performance of ground consolidation at the Port of Brisbane was analysed and discussed. A total of three trial areas were chosen to study the behaviour of surcharge and vacuum consolidation. Dividing the degree of consolidation, settlement and lateral displacement/settlement ratio by this $\beta$-factor, provides a performance indicator that represents the returns per unit value of $\beta$. In such a comparison, the vacuum consolidation applied by Contractor A in S3A seems to be the most beneficial. The membraneless vacuum system application is also effective in terms of controlling lateral displacement. However, the field inclinometer data is very limited to make overall conclusions. Control of lateral displacement effectively in sensitive areas such as marine parks would benefit immensely by the application of vacuum pressure and thereby decreasing the required fill heights on the surface.

\section{Acknowledgement}

Writers acknowledge the support of the Port of Brisbane Corporation, Coffey Geotechnics and Austress Menard. The research funding from the Australia Research Council and Australia, Centre of Excellence for Geotechnical Science and Engineering is acknowledged. The assistance of Daniel Berthier of Austress Menard Bachy, Cynthia De Bok, Tine Birkemose and Chamari Bamunawita of Coffey Geotechnics is appreciated. More elaborate details of the contents discussed in the paper can also be found in previous publications of the first Author and his research students in Journal of Geotechnical and Geoenvironmental Engineering, ASCE, Australian Geomechanics Society and Canadian Geotechnical Journals, since the mid-1990s. Valuable comments from A/Prof Hadi Khabbaz of UTS are greatly appreciated. 


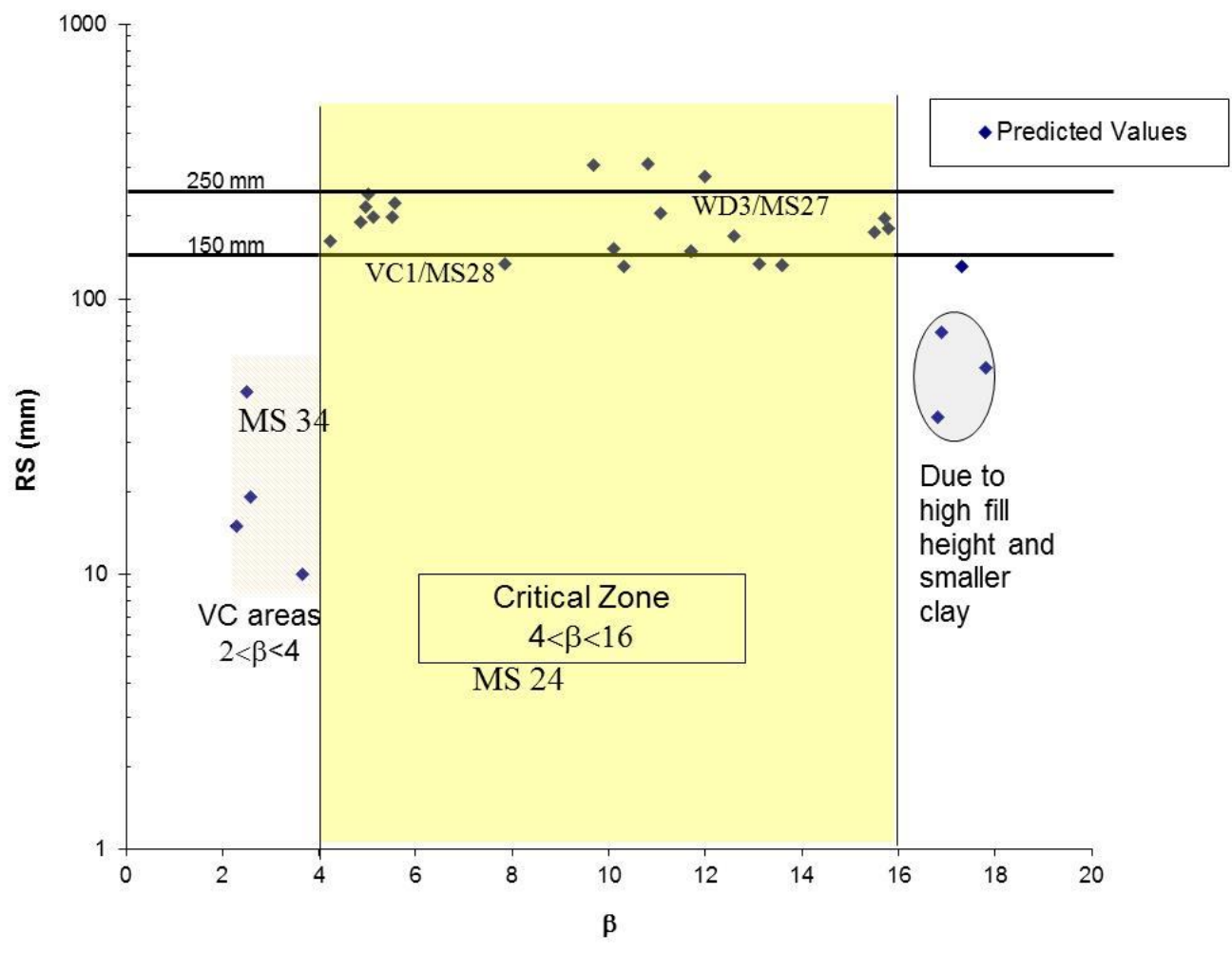

\section{Figure 8 Predicted residual settlements}

\section{References}

Ameratunga, J, Boyle, P, De Bok, C \& Bamunawita, C 2010, 'Port of Brisbane (PoB) clay characteristics and use of wick drains to improve deep soft clay deposits', Proceedings of the 17th Southeast Asian Geotechnical Conference (17SEAGS), pp. 116-119.

Chai, JC, Carter, JP \& Hayashi, S 2005, 'Ground deformation induced by vacuum consolidation', Journal of Geotechnical and Geoenvironmental Engineering, vol. 131, no. 12, pp. 1552-1561.

Chu, J, Yan, SW \& Yang, H 2000, 'Soil improvement by the vacuum preloading method for an oil storage station, Geotechnique, vol. 50, no. 6, pp. 625-632.

Holtz, RD, Jamiolkowski, M, Lancellotta, R \& Pedroni, S 1991, 'Prefabricated vertical drains: design and performance', in CIRIA ground engineering report: ground improvement, Butterworth-Heinemann Ltd, Oxford.

Indraratna, B \& Redana, IW 2000, 'Numerical modelling of vertical drains with smear and well resistance installed in soft clay', Canadian Geotechnical Journal, vol. 37, pp. 132-145.

Indraratna, B, Rujikiatkamjorn, C, Ameratunga, J \& Boyle, P 2011, 'Performance and prediction of vacuum combined surcharge consolidation at Port of Brisbane', Journal of Geotechnical \& Geoenvironmental Engineering, vol. 137, no. 11, pp. 1009-1018.

Indraratna, B, Sathananthan, I, Rujikiatkamjorn, C \& Balasubramaniam, AS 2005, 'Analytical and numerical modelling of soft soil stabilized by PVD incorporating vacuum preloading', International Journal of Geomechanics, vol. 5, no. 2, pp. 114-124.

Mohamedelhassan, E \& Shang, JQ 2002, 'Vacuum and surcharge combined one-dimensional consolidation of clay soils', Canadian Geotechnical Journal, vol. 39, pp. 1126-1138.

Rujikiatkamjorn, C, Indraratna, B \& Chu, J 2008, '2D and 3D numerical modeling of combined surcharge and vacuum preloading with vertical drains', International Journal of Geomechanics, vol. 8, no. 2, pp. 144-156.

Sathananthan, I, Indraratna, B \& Rujikiatkamjorn, C 2008, 'The evaluation of smear zone extent surrounding mandrel driven vertical drains using the cavity expansion theory', International Journal of Geomechanics, vol. 8, no. 6, pp. 355-365.

Shang, JQ, Tang, M \& Miao, Z 1998, 'Vacuum preloading consolidation of reclaimed land: a case study', Canadian Geotechnical Journal, vol. 35, pp. 740-749.

Terzaghi, K, Peck, RB \& Mesri, G 1996, Soil mechanics in engineering practice, 3rd edn, John Wiley \& Sons, Inc., New York, NY.

Yin, J-H \& Graham, J 1994, 'Equivalent times and one-dimensional elastic visco-plastic modelling of time-dependent stress-strain behaviour of clays', Canadian Geotechnical Journal, vol. 31, pp. 42-52. 
